\title{
ELECTROFISHING AS A SAMPLING TECHNIQUE FOR COASTAL STREAM FISH POPULATIONS AND COMMUNITIES IN THE SOUTHEAST OF BRAZIL
}

\author{
MAZZONI, R., ${ }^{1}$ FENERICH-VERANI, N. ${ }^{2}$ and CARAMASCHI, E. P. ${ }^{3}$ \\ ${ }^{1}$ Universidade do Estado do Rio de Janeiro, IB, DBAV, Setor de Zoologia, Pavilhão Haroldo Lisboa da Cunha, \\ $2^{\circ}$ andar, CEP 20559-900, Rio de Janeiro, RJ, Brazil \\ ${ }^{2}$ Universidade Federal de São Carlos, IB, DH \\ ${ }^{3}$ Universidade Federal do Rio de Janeiro, IB, DE \\ Correspondence to: Rosana Mazzoni, Universidade do Estado do Rio de Janeiro, IB, DBAV, Setor de \\ Zoologia, Pavilhão Haroldo Lisboa da Cunha, 2o andar, CEP 20559-900, Rio de Janeiro, RJ, Brazil, \\ e-mail: mazzoni@ism.com.br \\ Received July 24, 1998 - Accepted October 25, 1999 - Distributed May 31, 2000
}

(With 4 figures)

\begin{abstract}
Electrofishing adequacy was tested as a technique to obtain quantitative data of coastal stream fish populations and communities in the Southeast of Brazil. Seven field trips, between July/94 and July/ 95, were done in 5 localities of the Ubatiba fluvial system (Maricá, RJ). Seventeen species, among the 22 collected, had their numbers estimated through the Zipping method, the model used to test the sampling methodology. At each field trip, three removals with electrofishing were done in each locality and, according to the number of obtained species at each locality/field trip, we analysed 315 cases. Nineteen cases, among 315, showed failure condition. Estimates were significant ( $p<0.01$ ) in 96\% of the studied cases. Non-significant cases were obtained for rare species due to over and randomly efficient electrofishing in $63.3 \%$ and $36.4 \%$ of the cases, respectively. No correlation was found between catchability and the estimated number of individuals and/or environmental characteristics. High values for sampling efficiency ( $>85 \%)$ were found for all estimates. An experimental analyses were done for one locality and, the comparison between the estimates for 3 and 6 successive removals showed a mean error and a standard deviation of $5.5 \%$ and $2.1 \%$ respectively. Therefore, it can be concluded that electrofishing was an efficient method for quantitative data analysis of fish populations and communities in the Ubatiba fluvial system.
\end{abstract}

Key words: electrofishing, coastal streams, east basin, Brazil.

\section{RESUMO}

\section{A pesca elétrica como técnica de amostragem de populações e comunidades de peixes em rios costeiros do sudeste do Brasil}

Foi testada a adequacidade da pesca elétrica como técnica para a obtenção de dados quantitativos de populações e comunidades de peixes de riachos do sudeste do Brasil. Para isso, realizamos sete campanhas, entre julho/94 e julho/95, em cinco localidades do sistema fluvial do Ubatiba (Maricá, RJ). Das 22 espécies coletadas, 17 tiveram suas abundâncias estimadas pelo método de Zippin, que foi o modelo escolhido para testar a eficiência da metodologia de coleta. Em cada campanha, três remoções, com pesca elétrica, eram realizadas para cada localidade e, considerando o número (variável) de espécies obtidas por localidade/campanha, totalizaram-se 315 casos analisados. Dezenove casos, entre os 315, apresentaram condição de falha. As estimativas foram significativas $(\mathrm{p}<0.01)$ em 96,2\% dos casos analisados. Os casos não significativos ocorreram para as espécies raras e tiveram como causa a pesca supereficiente em $63,3 \%$ dos casos e randomicamente-eficiente em $36,4 \%$. Não foram observadas correlações entre a capturabilidade e a abundância estimada de indivíduos e/ou as características ambientais 
das diferentes localidades. Altos valores de eficiência amostral (> 85\%) foram registrados para todas as estimativas. Uma análise experimental foi realizada em uma localidade selecionada e a comparação entre as estimativas para 3 e 6 remoções sucessivas apontaram um erro médio e desvio-padrão de 5,5\% e $2,1 \%$, respectivamente. Concluímos que a pesca elétrica mostrou-se eficiente na obtenção de dados quantitativos das populações e comunidades de peixes do sistema fluvial do Ubatiba.

Palavras-cahve: pesca elétrica, rios costeiros, bacia Leste, Brasil.

\section{INTRODUCTION}

Obtaining quantitative data is one of the major problems in fish ecology studies and sampling methods are the main limitation for such studies (Pavanelli \& Caramaschi, 1997). Electrofishing has been broadly used in Temperate countries of the Northern hemisphere, since the beginning of this century (Hartley, 1990) and it is considered one of the most adequate methods for obtaining quantitative data of stream fish populations and communities.

In most of the Neotropical countries, if not in all of them, it is believed that electrofishing is inefficient even for qualitative studies (LobónCerviá et al., 1994). Because of this, fish population and communities studies have been exclusively based on data obtained by net fishing or other similar methods.

The electrofishing technique was recently introduced in Brazil for fish ecology studies. The first known publication is an evaluation of this method for fish population quantification in the Brazilian Pampa streams (Lobón-Cerviá et al., 1994). Three other studies were recently performed (Penczak et al., 1994; Agostinho \& Penczak, 1995; Severi et al., 1995), although the last one only describes qualitative data.

In this work we evaluate electrofishing for quantitative studies of fish populations and communities in a coastal stream in the Southeast of Brazil. Our results are compared to other electrofishing data obtained in different regions of Brazil and at the Holartic region, according to data presented by Lobón-Cerviá et al. (1994).

\section{MATERIAL AND METHODS}

Samples were done in the Ubatiba River, a coastal fluvial system (Maricá, RJ), in the Southeast of Brazil (22 $60^{\prime} \mathrm{S}$ and $\left.42^{\circ} 48^{\prime} \mathrm{W}\right)$. It flows down through an area of about $18 \mathrm{~km}$, and discharges in the Maricá Lagoon.

Five localities (U1 - U5, Fig. 1), 4 Km apart from each other, were selected for this study. All localities had clear and transparent water, thus, bottom and fishes could be easily seen during sampling. Each locality was sampled on 7 occasions (July, September, November/1994 and January, March, May, July/1995) within an extension of 50 to $80 \mathrm{~m}$.

In order to determine width, depth and area of the sampling localities we described batimetric maps of transversal transects performed at every $5 \mathrm{~m}$ of the whole sampling area. Conductivity was measured twice: January (summer) and August (winter) and varied among the localities; the highest values $(\sim 400 \mu \mathrm{S})$ were found near the lagoon (Table 1).

Sampling was done according to the electrofishing technique, and alternate current generator of electric power $(900 \mathrm{~W}, 220 \mathrm{~V}, 1-2 \mathrm{~A})$ was used. A person with a small fishing net coupled to the generator was followed by an assistant, carrying another net (not coupled to the generator), both went from one edge to the other of the sampling locality removing all the fishes that were in the electric field. The two edges of the sampled area were blocked by a closing net $(0.5 \mathrm{~cm}$ of mesh size), so that no fish could go into or get out of the sampled locality (first assumption as it will be seen later).

This procedure was repeated three times ( 3 removals) at each studied locality and sampling month, summing up 105 removals ( 3 removals * 5 localities * 7 months). Therefore, applying a constant fishing effort ( $\sim 30 \mathrm{~min}$ for each fishing removal), three fishing removals were performed at each locality and, between each removal, a break of half of the time used in the first removal was done (second assumption as it will be seen later). 

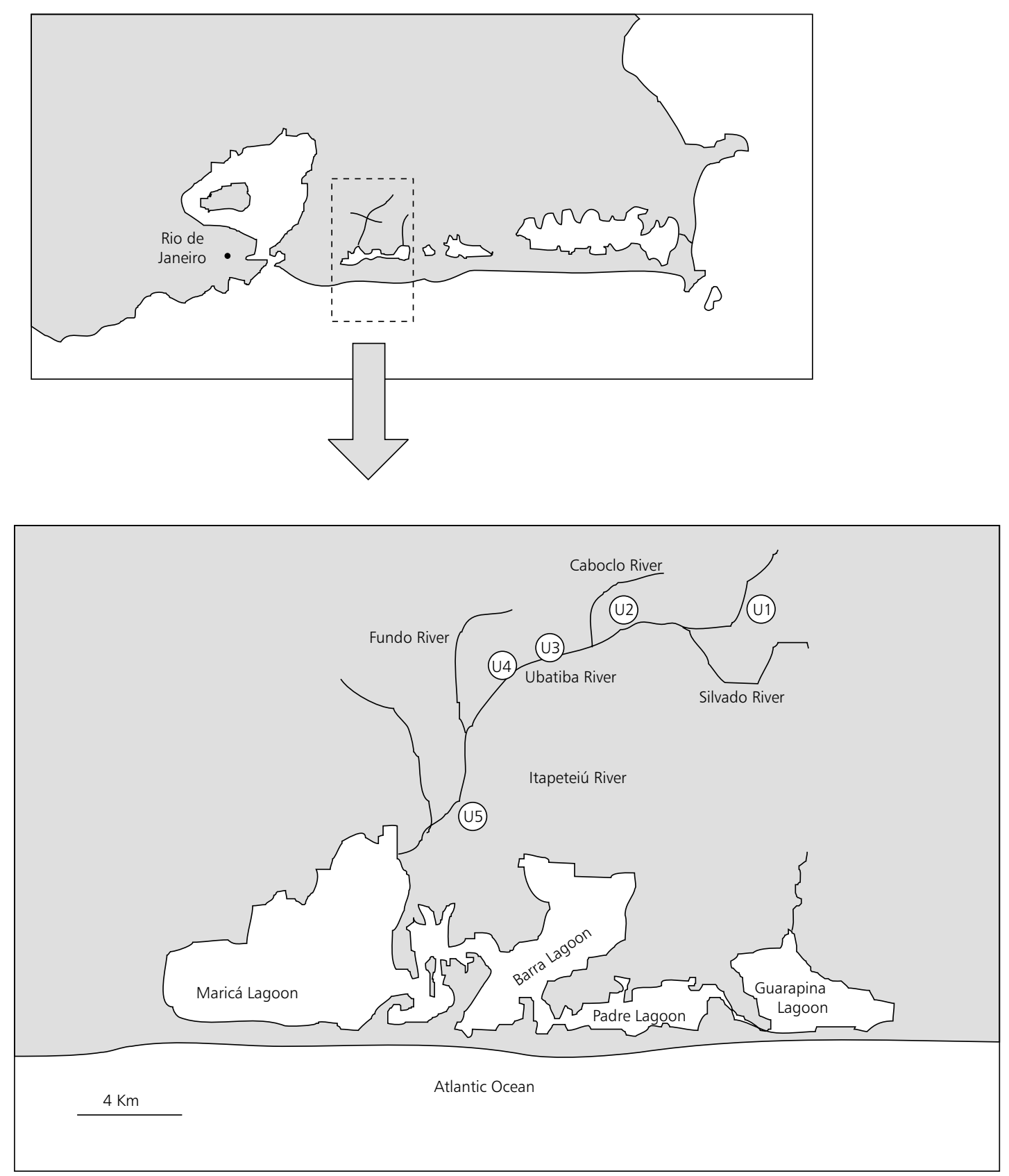

Fig. 1 - Sketch representing the Ubatiba fluvial system showing the sampling localities where the electrofishing method was used.

In order to test if the three removals were enough to estimate fish numbers, locality U5 was selected for an experimental study in July/1995; this choice was based upon the fact that U5 presented the largest number of fishes. In this case, instead of three fishing removals we performed removals until no fish was found in the sampling locality; six removals were needed for this. 
TABLE 1

Water conductivity recorded in two months and batimetric data obtained trough transversal transects $5 \mathrm{~m}$ apart from each other, including width, mean and standard deviation (SD); maximum depth, mean and standard deviation (SD) and sampling area, mean and standard deviation (SD), for the five studied localities in the Ubatiba fluvial system.

\begin{tabular}{|c|c|c|c|c|c|c|c|c|}
\hline \multirow{2}{*}{ Locality } & \multicolumn{2}{|c|}{$\begin{array}{c}\text { Conductivity } \\
(\boldsymbol{\mu} \text { S) }\end{array}$} & \multicolumn{2}{c|}{$\begin{array}{c}\text { Width } \\
(\mathbf{m})\end{array}$} & \multicolumn{2}{c|}{$\begin{array}{c}\text { Maximum depth } \\
(\mathrm{cm})\end{array}$} & \multicolumn{3}{c|}{ Area ( $\left.{ }^{\mathbf{2}}\right)$} \\
\cline { 2 - 10 } & August & January & Mean & SD & Mean & SD & Mean & SD \\
\hline U1 & 80 & 85 & 2.24 & 0.82 & 48.70 & 13.19 & 195.14 & 27.39 \\
\hline U2 & 90 & 95 & 1.53 & 0.72 & 40.10 & 8.99 & 135.29 & 36.05 \\
\hline U3 & 110 & 110 & 1.72 & 0.93 & 49.62 & 12.81 & 109.14 & 34.23 \\
\hline U4 & 180 & 140 & 1.96 & 0.95 & 54.00 & 15.93 & 132.71 & 42.67 \\
\hline U5 & 380 & 400 & 2.09 & 0.90 & 45.72 & 11.56 & 114.43 & 29.65 \\
\hline
\end{tabular}

The sketch presented in Fig. 2 shows the electrofishing procedure. Removed fishes were placed in floating cages and kept alive outside the electric field; all the individuals were measured (considering species and removals separately) and returned alive to the water, in the middle of the sampling area.

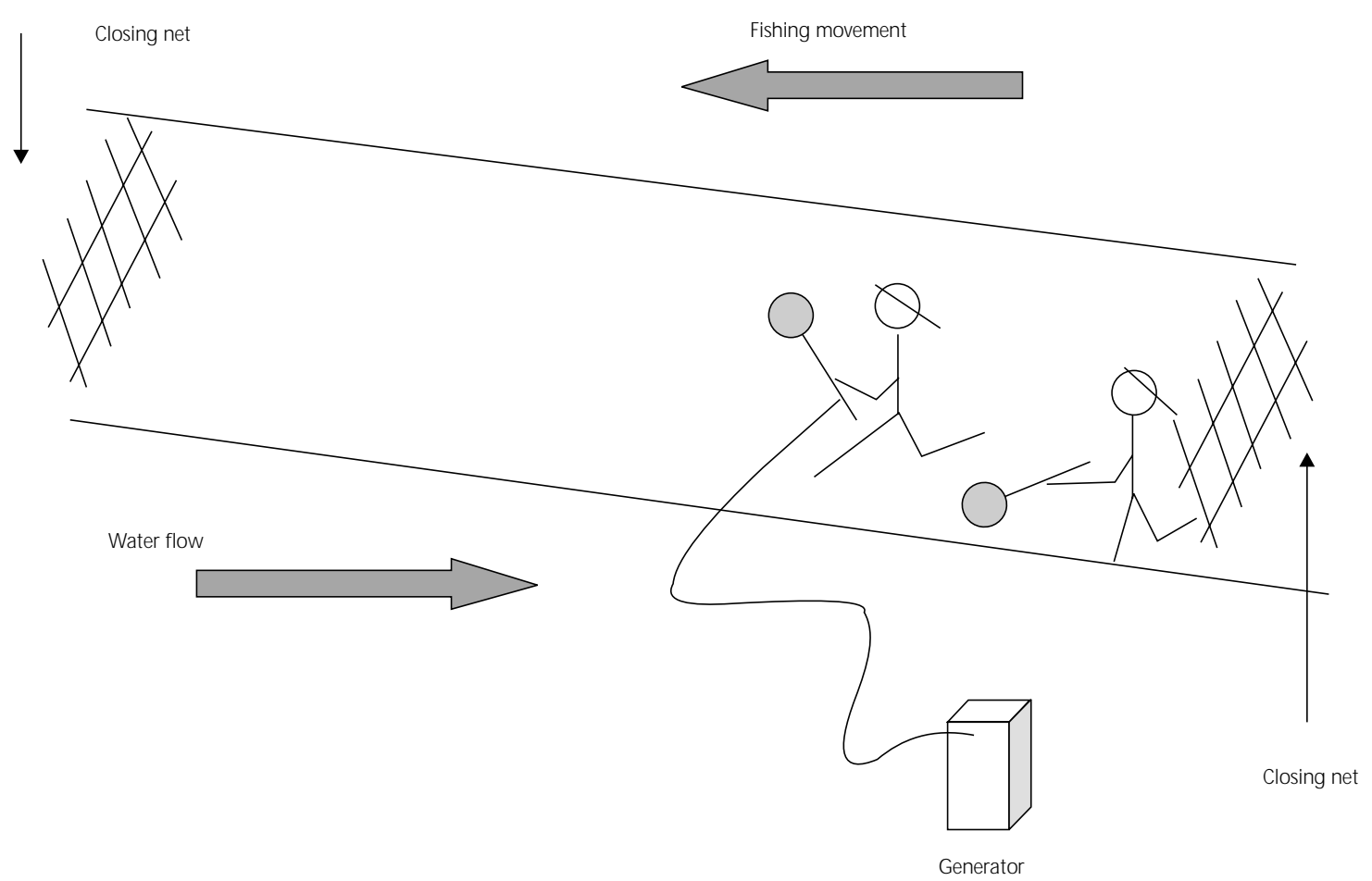

Fig. 2 - Sketch representing the procedures used for the electrofishing method in the Ubatiba fluvial system. 
In order to test electrofishing efficiency we opted for the use of the Zippin method (= Removal Method) (Zippin, 1958) as it allows population quantification, (estimate of fish number, $n$, catchability, $p$, and their respective variances, $V n$ and $V p$ ), and also helps to establish fishing adequacy measurements, such as: catchability constancy, failure condition and sampling efficiency.

Catchability constancy (CC) was tested by $\mathrm{T}_{1}$ values (Seber, 1982), which presume a binomial distribution for the number of removed fishes, considering three consecutive fishing removals and a constant effort. We considered significant values of $\mathrm{T}_{1}$ for $\mathrm{p}<0.05$, which means a significant estimate. Non significant estimates were considered as those in which the catchability was not constant, and according to Lobón-Cerviá et al. (1994), there are three ways to explain those cases: (i) "overefficient fishing", when in the first removal $\left(\mathrm{R}_{1}\right)$ at least $60 \%$ of the total sampling was removed; (ii) "under-efficient fishing", when in the first removal $\left(R_{1}\right) 30 \%$ or less of the total sampling was removed and (iii) "randomly efficient fishing", when in the first removal; regardless the effort, an unpredictable number of fishes was removed.

Failure condition (FC) follows the model [S $(\mathrm{s}+1-2 \mathrm{i}) \mathrm{Ci}]<0$, where $\mathrm{s}=$ total of fishing removals; $i=$ fishing removal (in this case 1,2 and 3 ) and $\mathrm{Ci}=$ number of captured individuals at the $\mathrm{i}^{\text {th }}$ fishing removal. In this model a ponderation is established; the number of caught individuals has to decrease at each removal, otherwise the FC is checked; therefore, it would be meaningless to estimate fish abundance of that population. Both CC and FC were obtained with the help of a software presented in Lobón-Ceviá (1991).

The sampling efficiency (SE) represents the proportion between the number of caught and estimated individuals, i.e. $\mathrm{SE}=100 \mathrm{Ct} / \tilde{n}$, where $\mathrm{Ct}=$ number of caught individuals in the total fishing removals and $\tilde{\mathrm{n}}=$ estimated number of individuals. As it is a proportional measurement, the efficiency of the method increases at the same pace as the SE result.

The use of the Zippin method is conditioned to three assumptions: (i) the studied population is closed, i.e. no individual goes into or out of the sampling area during the experiment; (ii) fishing effort is constant, i.e. fishing time is the same for all fishing removals; (iii) catchability is constant, i.e. the probability of being caught is the same for each of the individuals in the population.

The Zippin Method model is presented below and the only way to solve it is iteratively:

$$
\mathrm{f}(\mathrm{x})=\left(\mathrm{N} ! /(\mathrm{N}-\mathrm{Ct}) ! * \sum_{\mathrm{i}=1}^{\mathrm{s}} \mathrm{Ci}\right) * \mathrm{p}^{\mathrm{Ct}} * \mathrm{q}^{\mathrm{s}{ }^{* \mathrm{~N}}} * \sum_{\mathrm{i}=1}^{s+1} * \mathrm{Ki}
$$

solving the model we obtain the solutions of $\mathrm{N}$ and p:

$$
\begin{aligned}
& \mathrm{N}=\mathrm{Ct} /\left(1-\mathrm{q}^{\mathrm{s}}\right) \quad \text { and } \\
& \mathrm{q} / \mathrm{p}-\mathrm{s}^{*} \mathrm{q}^{\mathrm{s}} /\left(1-\mathrm{q}^{\mathrm{s}}\right)=\sum_{\mathrm{i}=1}^{\mathrm{s}}(\mathrm{i}-1) * \mathrm{Ci} / \mathrm{Ct}=\mathrm{R}
\end{aligned}
$$

where: $\mathrm{N}=$ estimated number of individuals, $\mathrm{Ct}=$ total number of caught individuals, $\mathrm{Ci}=$ number of caught individuals in the $\mathrm{i}^{\text {th }}$ removal, $\mathrm{p}=$ individual probability of being caught, $\mathrm{q}=\mathrm{p}$ complement, $\mathrm{K}=$ capturability and $\mathrm{S}=$ total number of removals.

Average catchability (p) was tested, through ANOVA in order to verify differences between localities and months. Multiple regressions were also done, to test the relationship between environmental parameters (width, depth, area and sampled volume), estimated fish abundance and $p$ values of each locality. Considering the experimental removals at U5 (July/95), we calculated the percentage error of estimated numbers when 3 and 6 removals were considered; for this the following model was used: $100-(\tilde{\mathrm{n} C 6} / \tilde{\mathrm{n} C} 3 * 100)$, where $\tilde{\mathrm{nC}} 3=$ estimated numbers of individuals for 3 removals and $\tilde{\text { CC}} 6=$ estimated numbers of individuals for 6 removals. Regression analysis was also done for the estimated number of individuals and the percentage error considering 3 and 6 removals.

\section{RESULTS}

Twenty-two species were registered in the 5 studied localities. Five of them, Awaous tajasica, Hyphessobrycon bimaculatus, Hyphessobrycon reticulatus, Rivulus janeiroensis and Tilapia sp., had occasional occurrence, so they were not considered in this work.

\section{Fishing efficiency for community}

Considering 105 removals related to 7 sampling occasions (July/94 to July/95) at 5 localities and a variable number of species at each 
locality, a total of 315 cases were analyzed. Nineteen $(6.03 \%)$ presented failure condition (FC), therefore, they were not included in the abundance estimates (Table 2).

Using the Zippin method, 285 of the 296 remaining cases $(96.28 \%)$ were significant $(=285$ constant catchability $[\mathrm{CC}]$ ), i.e. constant catchability with $\mathrm{T}_{1}$ for $\mathrm{p}<0.05$. The maximum number of non- significant estimates was 6 , among 57 , for the U3 locality. CC occurrence in the five localities of this study and catchability values (p) was higher than the data mentioned in the literature (Table 3 ).

There was no difference between $p$ values of each locality (ANOVA; $F=1.59 ; \mathrm{p}=0.18$ ). In this way, mean $p$ values were established for each period of time, considering all the localities (Fig. 3).

TABLE 2

Total of analysed cases (cases) and failure condition (FC) for each locality and species, between July/1994 and July/1995.

\begin{tabular}{|c|c|c|c|c|c|c|c|c|c|c|}
\hline & \multicolumn{2}{|c|}{ U1 } & \multicolumn{2}{|c|}{$\mathbf{U} 2$} & \multicolumn{2}{|c|}{$\mathbf{U 3}$} & \multicolumn{2}{|c|}{$\mathbf{U} 4$} & \multicolumn{2}{|c|}{ U5 } \\
\hline & Cases & FC & Cases & FC & Cases & FC & Cases & FC & Cases & FC \\
\hline Astyanax janeiroensis & 6 & 1 & 7 & & 7 & & 7 & & 7 & 1 \\
\hline Callichthys callichthys & 4 & & 3 & & 1 & & 2 & 2 & & \\
\hline Characidium interruptum & & & 6 & 2 & 6 & 2 & 6 & & 5 & \\
\hline Characidium sp. & 7 & & 7 & & 1 & & 3 & 2 & & \\
\hline Deuterodon sp. & & & 7 & & 7 & & 7 & & 7 & \\
\hline Geophagus brasiliensis & 1 & 1 & 7 & & 7 & & 7 & & 7 & \\
\hline Hoplias malabaricus & & & 7 & & 7 & & 7 & 1 & 6 & 1 \\
\hline Hypostomus cf. punctatus & & & 7 & & 7 & & 7 & & 7 & \\
\hline Jenynsia multidentata & & & & & & & & & 6 & \\
\hline Mimagoniates microlepis & & & 3 & & & & 7 & & 6 & \\
\hline Phalloceros caudimaculatus & 7 & & 1 & 1 & 1 & & 2 & & & \\
\hline Pimelodella lateristriga & & & 7 & & 5 & & 6 & & 7 & \\
\hline Poecilia reticulata & & & & & & & & & 4 & \\
\hline Poecilia vivipara & & & 6 & 1 & 6 & & 7 & & 7 & \\
\hline Rhamdia sp. & & & 4 & & 3 & & 3 & 1 & 5 & 2 \\
\hline Rineloricaria sp. & & & & & & & & & 2 & 1 \\
\hline Synbranchus marmoratus & & & 4 & & 1 & & 5 & & 3 & \\
\hline Total & 25 & 2 & 76 & 4 & 59 & 2 & 76 & 6 & 79 & 5 \\
\hline
\end{tabular}

Multiple correlation established between $\mathrm{p}$ values and estimated fish abundance, width, depth, area and sampling volume, did not show significant values $(\mathrm{p}<0.01)$.

\section{Fishing efficiency for populations}

Considering all the localities and sampling periods, 8 species (among 17 analysed in this work) showed constant catchability (CC) in $100 \%$ of the cases. Eleven cases, grouping nine species, did not showed constant $\mathrm{p}$ (Table 4), being seven of them $(63.6 \%)$ due to over-efficient electrofishing and four of them (36.4\%) due to randomly efficient electrofishing; there was no recorded data of under-efficient fishing among the non significant estimates.

Rineloricaria sp., C. callichthys, Rhamdia sp. and $C$. interruptum presented the highest percentage of $\mathrm{FC}<0$; moreover, it is important to notice that $\mathrm{FC}<0$ occurred only for rare species ( $<10$ fishes, after 3 successive removals) (Table 5). 
TABLE 3

Analysed cases without FC (cases), number (CC) and percentage (\% CC) of significant estimates, average (p) and range (range) of catchability, obtained by fish abundance estimates (Zippin Method) using 3 sucessive removals by electrofishing, for the five studied localities at Ubatiba River, and data obtained in the literature.

\begin{tabular}{|c|c|c|c|c|c|c|}
\hline Lacality & Cases & $\mathbf{C C}$ & $\mathbf{\% C C}$ & $\mathbf{p}$ & Range & Reference \\
\hline U1 & 23 & 22 & 95.7 & 0.70 & $0.99-0.42$ & this work \\
\hline U2 & 72 & 71 & 98.6 & 0.64 & $0.99-0.18$ & this work \\
\hline U3 & 57 & 51 & 89.5 & 0.65 & $0.99-0.18$ & this work \\
\hline U4 & 70 & 69 & 98.6 & 0.67 & $0.99-0.22$ & this work \\
\hline U5 & 74 & 72 & 97.3 & 0.60 & $0.99-0.18$ & this work \\
\hline Mesta/Bulgaria & 5 & - & 40.0 & 0.55 & $0.65-0.41$ & Penczak et al., 1985 \\
\hline Jarama/Espanha & 3 & - & 33.3 & 0.48 & $0.74-0.29$ & Lobón-Cerviá \& Penczak, 1984 \\
\hline O. Sebaou/Argelia & 3 & - & 100.0 & 0.63 & $0.71-0.48$ & Penczak \& Molinski, 1984 \\
\hline Pilawa/Polonia & 6 & - & 83.3 & 0.56 & $0.67-0.49$ & Penczak et al., 1986 \\
\hline Todasana/Venezuela & 3 & - & 100.0 & 0.52 & $0.63-0.39$ & Penczak \& Lasso, 1991 \\
\hline Campus/Brazil & 4 & - & 47.8 & 0.55 & $0.74-0.34$ & Lobón-Cerviá et al., 1994 \\
\hline Barbará/Brazil & 3 & - & 33.3 & 0.46 & $0.70-0.12$ & Lobón-Cerviá et al., 1994 \\
\hline
\end{tabular}

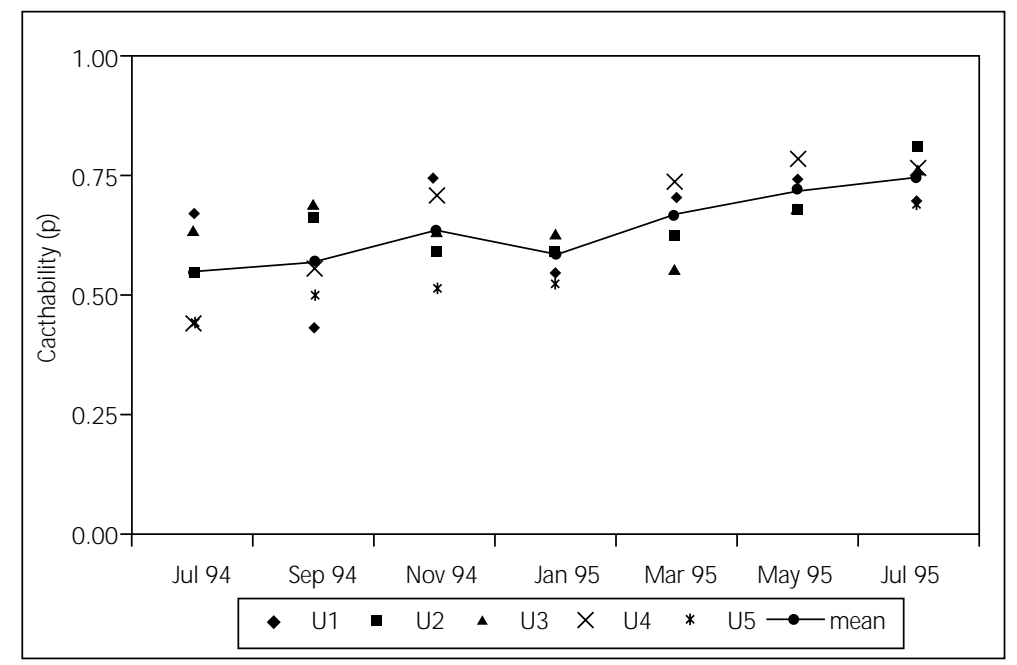

Fig. 3 - Graphical representation of the space/time variation of average catchability (p), for the species of the five studied localities in the Ubatiba fluvial system.

The average sampling efficiency (SE) was evaluated for each species and locality. Some species showed $100 \%$ of SE for all of the analysed cases and most showed high values for SE ( $>$ $85.0 \%$ ). The lowest SE values were $74.1 \%$ and $72.1 \%$, for P. vivipara and J. multidentata (both Cyprinodontiforms), respectively (Table 6). The relationship between conductivity and average SE of the different species indicates that the SE does not change according to the water conductivity of the Ubatiba River (Fig. 4).

Considering the number of removed fishes as an independent variable (CT), no significant correlation $(\mathrm{p}<0.01)$ was found with catchability $(\mathrm{p})$, sampling efficiency (SE) or percentage of significant cases $(\% \mathrm{CC})$. 
TABLE 4

Number of analysed cases (n TOT), number (n FC) and percentage (\%FC) of failure condition, total number of estimates (n-FC), number (n CC) and percentage (\%CC) of significant estimates (= constant catchability), average (p) and range of catchability, using 3 sucessive removals by electrofishing, for 17 out of the 22 sampled species in the Ubatiba River.

\begin{tabular}{|l|c|c|c|c|c|c|c|c|}
\hline \multicolumn{1}{|c|}{ Species } & n TOT & $\mathbf{n ~ F C}$ & $\mathbf{\% F C}$ & $\mathbf{n - F C}$ & $\mathbf{n ~ C C}$ & $\mathbf{\% C C}$ & $\mathbf{p}$ & Range \\
\hline Astyanax janeiroensis & 34 & 2 & 5.9 & 32 & 31 & 96.9 & 0.61 & $0.99-0.36$ \\
\hline Callichthys callichthys & 10 & 2 & 20.0 & 8 & 8 & 100 & 0.83 & $0.99-0.42$ \\
\hline Characidium interruptum & 23 & 4 & 17.4 & 19 & 18 & 94.7 & 0.68 & $0.99-0.30$ \\
\hline Characidium sp. & 18 & 2 & 11.1 & 16 & 15 & 93.8 & 0.69 & $0.99-0.39$ \\
\hline Deuterodon sp. & 28 & 0 & 0 & 28 & 27 & 96.4 & 0.57 & $0.83-0.22$ \\
\hline Geophagus brasiliensis & 29 & 1 & 3.4 & 28 & 26 & 92.9 & 0.57 & 0.840 .26 \\
\hline Hoplias malabaricus & 27 & 2 & 7.4 & 25 & 25 & 100 & 0.66 & $0.99-0.18$ \\
\hline Hypostomus cf. punctatus & 28 & 0 & 0 & 28 & 27 & 96.4 & 0.62 & $0.99-0.26$ \\
\hline Jenynsia multidentata & 6 & 0 & 0 & 6 & 6 & 100 & 0.49 & $0.99-0.16$ \\
\hline Mimagoniates microlepis & 16 & 0 & 0 & 16 & 16 & 100 & 0.70 & $0.83-0.54$ \\
\hline Phalloceros caudimaculatus & 11 & 1 & 9.1 & 10 & 10 & 100 & 0.69 & $0.99-0.14$ \\
\hline Pimelodella lateristriga & 25 & 0 & 0 & 25 & 23 & 92.0 & 0.65 & $0.99-0.21$ \\
\hline Poecilia reticulata & 4 & 0 & 0 & 4 & 4 & 100 & 0.82 & $0.99-0.57$ \\
\hline Poecilia vivipara & 26 & 1 & 3.8 & 25 & 24 & 96.0 & 0.49 & $0.99-0.25$ \\
\hline Rhamdia sp. & 15 & 3 & 20.0 & 12 & 12 & 100 & 0.69 & $0.99-0.18$ \\
\hline Rineloricaria sp. & 2 & 1 & 50.0 & 1 & 1 & 100 & 0.75 & $0.99-0.51$ \\
\hline Synbranchus marmoratus & 13 & 0 & 0 & 13 & 12 & 92.3 & 0.80 & $0.99-0.27$ \\
\hline
\end{tabular}

TABLE 5

Total of analysed cases for the species that presented FC $<0$ (TAC), percentage of FC $<0$ (\%FC), maximum (Nmax) and minimum (Nmin) of caughted individuals after 3 removals and maximum of caughted individuals in cases with $\mathrm{FC}<0$ (NmaxFC) at the five studied localities during the seven sampling periods.

\begin{tabular}{|l|c|c|c|c|c|}
\hline \multicolumn{1}{|c|}{ Species } & TAC & \%FC & Nmax & Nmin & NmaxFC \\
\hline Astyanax janeiroensis & 34 & 5.9 & 511 & 2 & 10 \\
\hline Callichthys callichthys & 10 & 20.0 & 5 & 1 & 1 \\
\hline Characidium interruptum & 23 & 17.4 & 40 & 1 & 4 \\
\hline Characidium sp. & 18 & 11.1 & 55 & 1 & 1 \\
\hline Geophagus brasiliensis & 29 & 3.4 & 573 & 1 & 1 \\
\hline Hoplias malabaricus & 27 & 7.4 & 20 & 1 & 3 \\
\hline Phalloceros caudimaculatus & 11 & 9.1 & 375 & 1 & 1 \\
\hline Poecilia vivipara & 26 & 3.8 & 734 & 6 & 6 \\
\hline Rhamdia sp. & 15 & 20.0 & 30 & 1 & 5 \\
\hline Rineloricaria sp. & 2 & 50.0 & 14 & 1 & 1 \\
\hline
\end{tabular}

\section{Case study at U5}

Six successive removals were needed so that no other fishes would be caught in U5. So, the estimate values of the first 3 removals were compared to the estimates of the six removals. The percentage error found varied from $2.8 \%$ for Deuterodon sp. to $9.0 \%$ for C. interruptum (Table 7). 


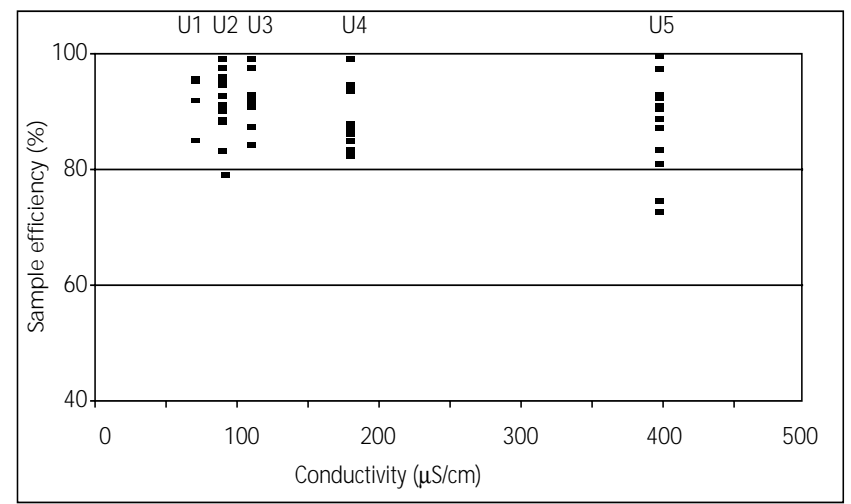

Fig. 4 - Graphical representation of the relationship between conductivity and average sampling efficiency (SE) of the different species in the studied localities in the Ubatiba fluvial system.

TABLE 6

Average values of sampling efficiency (SE) and number of significant estimates (n) of the species caught at each locality of the Ubatiba fluvial system.

\begin{tabular}{|l|c|c|c|c|c|c|c|c|c|c|}
\hline \multirow{2}{*}{ Species } & \multicolumn{2}{c|}{ U1 } & \multicolumn{2}{c}{ U2 } & \multicolumn{2}{c|}{ U3 } & \multicolumn{2}{c|}{ U4 } & \multicolumn{2}{c|}{ U5 } \\
\cline { 2 - 10 } & SE & $\mathbf{n}$ & SE & $\mathbf{n}$ & SE & $\mathbf{n}$ & SE & n & SE & n \\
\hline Astyanax janeiroensis & 95.1 & 5 & 95.8 & 5 & 91.7 & 5 & 85.6 & 6 & 92.2 & 6 \\
\hline Callichthys callichthys & 91.7 & 4 & 94.4 & 4 & 100.0 & 1 & 100.0 & 2 & & \\
\hline Characidium interruptum & & & 95.4 & 5 & 100.0 & 5 & 93.3 & 7 & 80.5 & 6 \\
\hline Characidium sp. & 95.5 & 7 & 88.3 & 5 & 100.0 & 1 & 87.5 & 5 & & \\
\hline Deuterodon sp. & & & 97.3 & 6 & 91.5 & 6 & 81.7 & 7 & 89.8 & 6 \\
\hline Geophagus brasiliensis & & & 90.9 & 7 & 92.8 & 6 & 86.5 & 5 & 91.8 & 7 \\
\hline Hoplias malabaricus & & & 89.9 & 7 & 87.2 & 5 & 100.0 & 7 & 97.6 & 6 \\
\hline Hypostomus cf. punctatus & & & 82.9 & 7 & 84.2 & 6 & 94.4 & 7 & 90.1 & 5 \\
\hline Jenynsia multidentata & & & & & & & & & 72.1 & 6 \\
\hline Mimagoniates microlepis & & & 100.0 & 3 & & & 94.1 & 7 & 82.7 & 6 \\
\hline Phalloceros caudimaculatus & 84.8 & 4 & 100.0 & 2 & 100.0 & 1 & 100.0 & 2 & & \\
\hline Pimelodella lateristriga & & & 88.1 & 5 & 97.2 & 5 & 84.5 & 6 & 87.8 & 6 \\
\hline Poecilia reticulata & & & & 2 & & & & & 100.0 & 4 \\
\hline Poecilia vivipara & & & 79.0 & 6 & 90.6 & 6 & 83.1 & 5 & 74.1 & 7 \\
\hline Rhamdia sp. & & & 92.3 & 5 & 91.7 & 4 & 86.7 & 3 & 91.8 & 5 \\
\hline Rineloricaria sp. & & & 100.0 & 3 & 100.0 & 1 & 100.0 & 4 & 86.5 & 3 \\
\hline Synbranchus marmoratus & & & & & & & 82.5 & 3 \\
\hline
\end{tabular}

Correlation analysis between the estimated number of individuals (for 3 or 6 removals) and the percentage error between 3 and 6 removals, showed significant inverse correlation $\left(\mathrm{r}^{2}=-0.68 ; \mathrm{p}<0.001\right)$, indicating that the highest error values are related to rare species.

\section{DISCUSSION}

An indirect measurement of electrofishing efficiency in the fluvial system of the Ubatiba River is given by the list of species here presented. Considering precisely the same sampling localities, 
Costa (1984) only presented 15 of the 22 species that we recorded in this work. Electrofishing efficiency has already been demonstrated in several papers, for the quantification of fish populations (Lobón et al., 1994), in habitat usage studies (Baras,
1995) or qualitative surveys of fish populations and communities (Severi et al., 1995). Penczak \& Rodriguez (1990) have demonstrated the importance of this technique even for decapods population in Venezuela.

TABLE 7

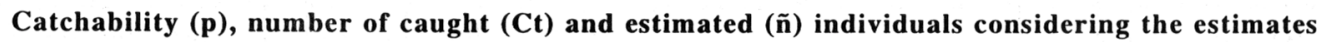
for 3 (C3) and for 6 (C6) successive removals and total error for estimated individuals when 3 removals were considered (\% error in $\mathbf{C 3}$ ).

\begin{tabular}{|c|c|c|c|c|c|c|c|}
\hline \multirow{2}{*}{ Species } & \multicolumn{3}{|c|}{$\mathbf{C 3}$} & \multicolumn{3}{|c|}{ C6 } & \multirow{2}{*}{ \% error in $\mathrm{C} 3$} \\
\hline & $\mathbf{C t}$ & $\tilde{\mathbf{n}}$ & $\mathbf{p}$ & $\mathbf{C t}$ & $\tilde{\mathbf{n}}$ & $\mathbf{p}$ & \\
\hline Characidium interruptum & 7 & 10 & 0.37 & 9 & 11 & 0.43 & 9.0 \\
\hline Hypostomus cf. punctatus & 10 & 13 & 0.38 & 12 & 14 & 0.16 & 7.1 \\
\hline Pimelodella lateristriga & 11 & 12 & 0.69 & 13 & 13 & 0.42 & 7.7 \\
\hline Astyanax janeiroensis & 30 & 32 & 0.57 & 34 & 34 & 0.43 & 5.9 \\
\hline Mimagoniates microlepis & 53 & 64 & 0.44 & 69 & 67 & 0.42 & 4.5 \\
\hline Geophagus brasiliensis & 75 & 84 & 0.39 & 84 & 88 & 0.32 & 4.5 \\
\hline Poecilia reticulata & 163 & 192 & 0.46 & 170 & 202 & 0.37 & 5.0 \\
\hline Poecilia vivipara & 163 & 193 & 0.46 & 170 & 199 & 0.37 & 3.0 \\
\hline Deuterodon sp. & 236 & 282 & 0.45 & 250 & 290 & 0.41 & 2.8 \\
\hline Mean & & & & & & & 5.5 \\
\hline Standard deviation & & & & & & & 2.1 \\
\hline
\end{tabular}

On the other hand, the low values of water conductivity in the Neotropical region have been extensively discussed and pointed as one of the most limiting factor for the use of electrofishing in that region. Agostinho \& Penczak (1995) stated that electrofishing is inefficient in tropical streams, due to the low water conductivity of such environments. In fact, there is an inverse correlation between fishing efficiency and water conductivity (Zalewski \& Cowx, 1990). However, fishing efficiency is also related to the type of electric current (AC or DC) and to the amperometric values; those parameters can be adjusted considering the conductivity of the studied stream water.

In this work it was evident, due to the high values of sampling efficiency (SE), that the water conductivity of the Ubatiba River cannot be considered a limiting factor for electrofishing use. Data about the frequency of significant estimates, in other regions where electrofishing was tested (Table 2), corroborates our results as we had significant estimates frequency similar or even higher than the values found in the literature.

Kennedy \& Strange (1981) discussed the stream width as a limiting factor to obtain quantitative data. In the case of the Ubatiba River no additional analysis related to the stream width was necessary, as none of the localities were more than 3 meters wide. On the other hand, field experiments in larger streams more than 5 meters wide, in the Tocantins dranaige showed that the use of more than one fishing net connected to the electric generator was an adequate solution for this problem (R.M., personal observation).

Non significant estimates are the ones in which catchability was not constant. In this work, $63.6 \%$ of the non-significant estimates were due to the over-efficient fishing, while $36.4 \%$ were characterized by randomly efficient fishing; underefficient fishing was not observed.

The failure condition (FC) can be treated as an electrofishing efficiency measurement for fish 
populations. It is noticeable that in the present work the failure condition was seldom recorded and only occurred for rare species. Nonetheless, it is important to notice that special care is required for the use of electrofishing for benthic species. Direct field observations, associated to the results of this study, showed that benthic species tend to be more difficult to be caught, as bottom characteristics make them inconspicuous.

Among the benthic species, two of them showed criptic habits (they hide in tunnels or caves in the river-bed), S. marmoratus and Rhamdia sp.; however the electrofishing technique was efficient even for these species.

Characiform species, such as A. janeiroensis and Deuterodon sp., deserve special attention, as they are highly motile and able to avoid the electric field. This problem can be easily solved using closing nets on the edges of the sampling area.

The removal method for abundance estimation has been widely used (e.g., Mahon et al., 1979; Penczak, 1981a; Penczak, 1981b; Agostinho \& Penczak, 1995). The number of removals used for each study is chosen in order to minimize the fishing effort without compromising the reproducibility of the data. We tested the results of 3 and 6 removals, at the same locality and sampling time, in order to quantify the differences between the two methods. The obtained average error was $5.5 \%$ (standard deviation $=2.1$ ) for three removals. The relationship between the percentage error and the number of sampled individuals showed an inverse correlation, indicating that rare species showed higher error when the three-removal method was used.

These results indicate that three removals should be enough for obtaining quantitative data, as the major errors were only found for the rare species, which minimize the total error, considering the abundance estimate for the studied localities.

It is important to mention that the electrofishing technique cannot be considered the solution for all the problems which involve fish sampling in streams. The imposed limitations for this method are mostly related to the size of the studied area; larger rivers, much wider and deeper than the localities studied here would not be suitable for sampling when using the electrofishing approach as described here.
On the other hand, the results presented clearly showed that electrofishing is perfectly suitable for quantitative analysis of fish populations in streams. It is worth mentioning that the two first works involving fish production estimation in Neotropical streams (Agostinho \& Penczak, 1995; Mazzoni, 1998) are directly related to the use of this technique for the sampling method, which suggests the importance of electrofishing for population quantification.

Considering that electrofishing is a good enough method for fish sampling in small rivers and that streams like the ones here described are very abundant in Brazil, we suggest the use of this method for obtaining quantitative data, in order to standardize discussions on fish ecology in that type of environment.

Acknowledgments - We acknowledge the Fish Ecology Laboratory staff of Universidade Federal do Rio de Janeiro and Universidade do Estado do Rio de Janeiro for their help working under a tropical sun at $40^{\circ} \mathrm{C}$. We also thank Ricardo Iglesias Rios, Javier Lobón-Cerviá, José Roberto Verani, Marisa Narciso Fernandes, Alberto Carvalho Peret and the anonymous referee for the patient reading of the manuscript and for the valuable suggestions. Special thanks to Chiara Mazzoni for this translation. This work is part of the requirements for the $\mathrm{PhD}$ thesis of the first author (PPG-ERN, Universidade Federal de São Carlos, CNPq grant).

\section{REFERENCES}

AgOstinhO, A. A. \& PENCZAK, T., 1995, Populations and production of fish in two small tributaries of the Paraná River, Paraná, Brazil. Hydrobiologia, 312: 153-166.

BARAS, E., 1995, An improved electrofishing methodology for the assessment of habitat use by young-ofthe-year fishes. Arch. Hydrobiol., 134: 403-415.

COSTA, W. J. E. M., 1984, Peixes fluviais do sistema lagunar de Maricá, Rio de Janeiro, Brasil. Rev. Atlântica, 7: 65-82.

HARTLEY, W. G., 1990, The history of electric fishing. In: I. G. Cowx \& P. Lamarque (eds.), Fishing With Electricity, Applications in Freshwater Fisheries Management. Fishing New Books.

KENNEDY, G. J. \& STRANGE, C. D., 1981, Efficiency of electric fishing for salmonids in relation to river width. Fish. Mgnt., 12: 55-60.

LOBÓN-CERVIÁ, J. \& PENCZAK, T., 1984, Fish production in the Jarama River, central Spain. Holarct. Ecol., 7: 128-137. 
LOBÓN-CERVIÁ, J., 1991, Dinámica de poblaciones de peces en rios: pesca eléctrica y métodos de capturas sucesivas en la estima de abundancias. Monografias Museo Nacional de Ciencias Naturales. Consejo Superior de Investigaciones Científicas, 157p.

LOBÓN-CERVIÁ, J., UTRILLA, C. \& QUEIROL, H., 1994, An evaluation of the 3-removal method with electrofishing techniques to estimate fish number in streams of the brazilian Pampa. Archive für Hydrobiologie, 130: 371-381.

MAHON, R., BALON, E. K. \& NOAKES, D. L. G., 1979, Distribution, community structure and production of fishes in the upper Speed River, Ontario: a preimpoudment study. Envir. Biol. Fish., 4: 219-244.

MAZZONI, R., 1998. Estrutura das Comunidades e Produção de Peixes de um Sistema Fluvial Costeiro de Mata Atlântica, Rio de Janeiro. Tese de Doutorado, PPGERN, UFSCar, 100p

PAVANELLI, C. S. \& CARAMASCHI, E. P., 1997, Composition of the ichthyofauna of two small tributaries of the Paraná River, Porto Rico, Paraná State, Brazil. Ichthyol. Explor. Freshw., 8: 23-31.

PENCZAK, T., 1981a, Problems of river ichthyology. Jornadas de Ictiologia Ibérica. Léon, España.

PENCZAK, T., 1981b, Ecological fish production in two small lowland rivers in Poland. Oecologia, 48: 107111.

PENCZAK, T. \& MOLINSKI, M., 1984, Fish production in the Oued Sebaou, a seasonal river in north Algeria. J. Fish Biol., 25: 723-732.

PENCZAK, T., JANKOV, J., DIKOV, Ts. J. \& ZALEWSKI, M., 1985, Fish production in the Mesta River, Rila mountains, Samokov, Bulgaria. Fish. Res., 3: 201-221.
PENCZAK, T., LOBÓN-CERVIÁ, J., O'HARA, K. \& JAKUBOWSKI, H., 1986, Production and food consumption by fish populations in the Pilawa and Dobrzyca Rivers, North Poland. Pol. Arch. Hydrobiol., 33(3/4): 345-372.

PENCZAK, T. \& RODRIGUEZ, G., 1990, The use of electrofishing to estimate population densities of freshwater shrimps (Decapoda, Natantia) in a small tropical river, Venezuela. Arch. Hydrobiol., 118: 501-509.

PENCZAK, T. \& LASSO, C., 1991, Problems of estimating population parameters and production of fish in a tropical rain forest stream, north Venezuela. Hydrobiologia, 215: 121-133.

PENCZAK, T., AGOSTINHO, A. A. \& OKADA, E. K., 1994, Fish diversity and community structure in two small tributaries of the Paraná River, Paraná State, Brazil. Hydrobiologia, 294: 243-251.

SEBER, G. A. F., 1982, The Estimation of Animal Abundance and Related Parameters. Griffin Co., $2^{\text {nd }}$ Edition, London.

SEVERI, W., HICKSON, R. G. \& MARANHÃO, T. C. F., 1995, Use of electric fishing for fish fauna survey in southern Brazil. Rev. Brasil. Biol., 55: 631-660.

ZALEWSKI, M. \& COWX, I. G., 1990, Factors Affecting the Efficiency of Electric Fishing. In: I. G. Cowx \& P. Lamarque (eds.), Fishing With Electricity, Applications in Freshwater Fisheries Management. Fishing New Books.

ZIPPIN, C., 1958, The removal method of population estimation. Journ. Wild. Mgmt., 22: 82-90. 